Binghamton University

The Open Repository @ Binghamton (The ORB)

6-1-2003

\title{
Spatial Negotiations in a Commercial City: The Red Sea Port of Mocha, Yemen during the First Half of the Eighteenth Century
}

Nancy Um

Binghamton University--SUNY, nancyum@binghamton.edu

Follow this and additional works at: https://orb.binghamton.edu/art_hist_fac

Part of the Architectural History and Criticism Commons, and the History of Art, Architecture, and Archaeology Commons

\section{Recommended Citation}

Nancy Um, "Spatial Negotiations in a Commercial City: The Red Sea Port of Mocha, Yemen during the First Half of the Eighteenth Century," Journal of the Society of Architectural Historians 62:2 (June 2003): 178-193.

This Article is brought to you for free and open access by the Art History at The Open Repository @ Binghamton (The ORB). It has been accepted for inclusion in Art History Faculty Scholarship by an authorized administrator of The Open Repository @ Binghamton (The ORB). For more information, please contact ORB@binghamton.edu. 


\title{
Spatial Negotiations in a Commercial City
}

\author{
The Red Sea Port of Mocha, Yemen, \\ during the First Half of the Eighteenth Century
}

NANCY UM

Binghamton University

The government of Mocha is the best in the gift of the Imaum [sic]. . . They say, that when a Dola [governor] is appointed, he weighs nothing; that on going out of the gates of Sana [sic] he weighs a frasel; that on arriving at his government, he weighs two and goes on growing heavier and heavier during his stay.

-George Viscount Valentia

Voyages and Travels to India, Ceylon, the Red Sea, Abyssinia, and Egypt

\section{The Mocha Network in Yemen}

$\mathrm{T}$ he name Mocha, from the Arabic al-Mukha, entered the European imagination by way of the Arabian coffee beans that were shipped from the city's shore in high volumes during the seventeenth through the twentieth centuries. Although coffee is the port's most famous export, a wide variety of other commodities, including spices, metals, rice, sugar, aromatics, medicinal products, and textiles, was imported into, exported from, and shipped in the city, destined for Asian, African, and European shores.

While other Arabian seaports, such as Jiddah and Aden, present contemporary skylines that recall their historic volume of trade and importance, Mocha's only bears witness to numerous past attacks from both sea and land. Nothing of the pre-nineteenth-century city stands any longer, except for a few isolated historic mosques and the remains of fine merchants' houses (Figure 1). Were it not for those destruc- tive acts and the eventual decline of the port, one would be able to find the traces of a lively mercantile center today, distinguished from the modest surrounding towns of this lowland coastal plain by its multistoried, whitewashed merchants' houses. ${ }^{2}$

From the sixteenth through the nineteenth centuries, a diverse community of Yemeni officials and Indian Ocean merchants, who hailed from many different ports, defined the city's distinct maritime pulse. The Zaydi Qasimi imams held power in Yemen during the interim period between two different stages of Ottoman rule, the first ending in 1636 and the second beginning in 1835 . Throughout the eighteenth century, they controlled the port of Mocha administratively from the highlands of Yemen and monitored the profits of this international commercial hub, with an interest in protecting and promoting trade for the benefit of the inland royal treasury. While the imam's seat of power always remained in the highlands, the ports were important sources of revenue that allowed for the maintenance of the imam's troops and the stability of the whole dynasty. For this reason, the political thrust of Mocha's government came directly from the imam's capital in the northern mountainous region of Yemen, often in the form of the imam's officials who were sent to govern and oversee trade activity. Thus, the faraway imperial visions of Zaydi dynastic politics loomed large, affecting everyday life in the city.

Indian merchants played prominent roles in all parts of the trade, including high-profile ship-owning Muslim 
Gujaratis, such as the well-known 'Abd al-Ghafur and Mullah Muhammad 'Ali. Baniyan brokers and money changers, who were Hindu and Jain, lived in extended communities throughout the southern Arabian Peninsula as mercantile intermediaries. They served as the primary commercial middlemen at this port, using their linguistic skills to translate for their clients and to handle the details of exchange. Some other important participants in the international wholesale trade came from both sides of the Persian Gulf. Furthermore, traffic between Mocha and the African ports of the western coast of the Red Sea was continuous and vibrant.

Hence, Mocha presents a dualistic cultural identity, fixed between the highland dynastic world of an early modern Shi'i Arabian imamate and the world of maritime trade. Such a bifurcation is mirrored in the sources that serve as the foundation for its study during the early modern period. In the absence of extant buildings, text plays a central role in the process of historical reconstruction and the interpretation of city space.

The dynamics of trade and interaction in the Indian Ocean world are most clearly illuminated by the records of the Europeans, whose copious notes reveal the details of commerce and everyday life in the city. These documents are extremely valuable historically despite the fact that the Europeans were the smallest and least significant merchant community in the city. The Dutch, English, and French East India Companies each maintained a continuous residence in the city for parts of the early eighteenth century, and their trade and residential notes serve as the most voluminous and detailed eyewitness documentation of the city's history. In particular, the diaries left by the merchants associated with the Dutch East India Company (VOC) from the first half of the eighteenth century, now held in the General State Archives in The Hague, constitute the backbone of the present study. ${ }^{3}$ While these sources often reveal bias, frustration, and isolation on the part of the European community in the city, the nature of the continuous European presence allows for an unparalleled opportunity to monitor change over time in this historical era, thus making Mocha one of the best documented cities in all of Yemen during the period. ${ }^{4}$ Also, the Europeans considered Mocha important from a strategic and economic viewpoint, and the accuracy of their recorded observations was essential to the ongoing success of their trade. The Arabic sources from the era are much scantier in their details about daily life at the port, particularly because most were written from the distant vantage of the highland centers by official historians. But when these two groups of sources, European and Arabic, are read together, a precious perspective on the details

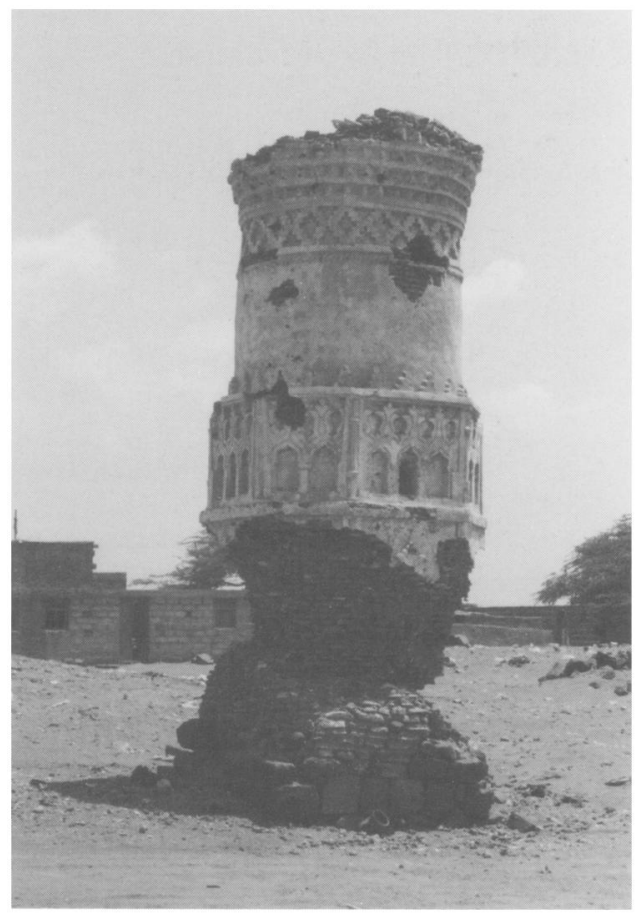

Figure 1 The crumbling minaret of the Mosque of Sayyidah Zaynab, an icon of Mocha's current state of ruin. The previously adjoining mosque collapsed during the mid-twentieth century. In the past few years, a new base was built to support this standing fragment.

of urban practices emerges. The VOC diaries govern the chronological scope of this essay, which focuses on the first half of the eighteenth century.

\section{Commercial Architecture in the Arab City}

Architectural studies of Arab capitals often center on the imperial and the monumental dimensions of building programs. The architectural structure of commercial interaction, therefore, has not constituted a major realm of scholarly inquiry. While imperial building and religious complexes can readily maintain pristine historic stature to the modern eye, commercial architecture, often still in use, is more difficult to place in historical perspective.

Potentially, fixed architectural typologies provide a strong basis for understanding the historical organization of urban commercial sectors in the Arab world. In his comprehensive study of Middle Eastern markets, Mohamed Scharabi has articulated a tripartite typological framework for commercial architecture that corresponds to a conventional understanding of market organization in the Islamic world and is supported by a number of wide-ranging examples in the North African, eastern Mediterranean, Turkish, 


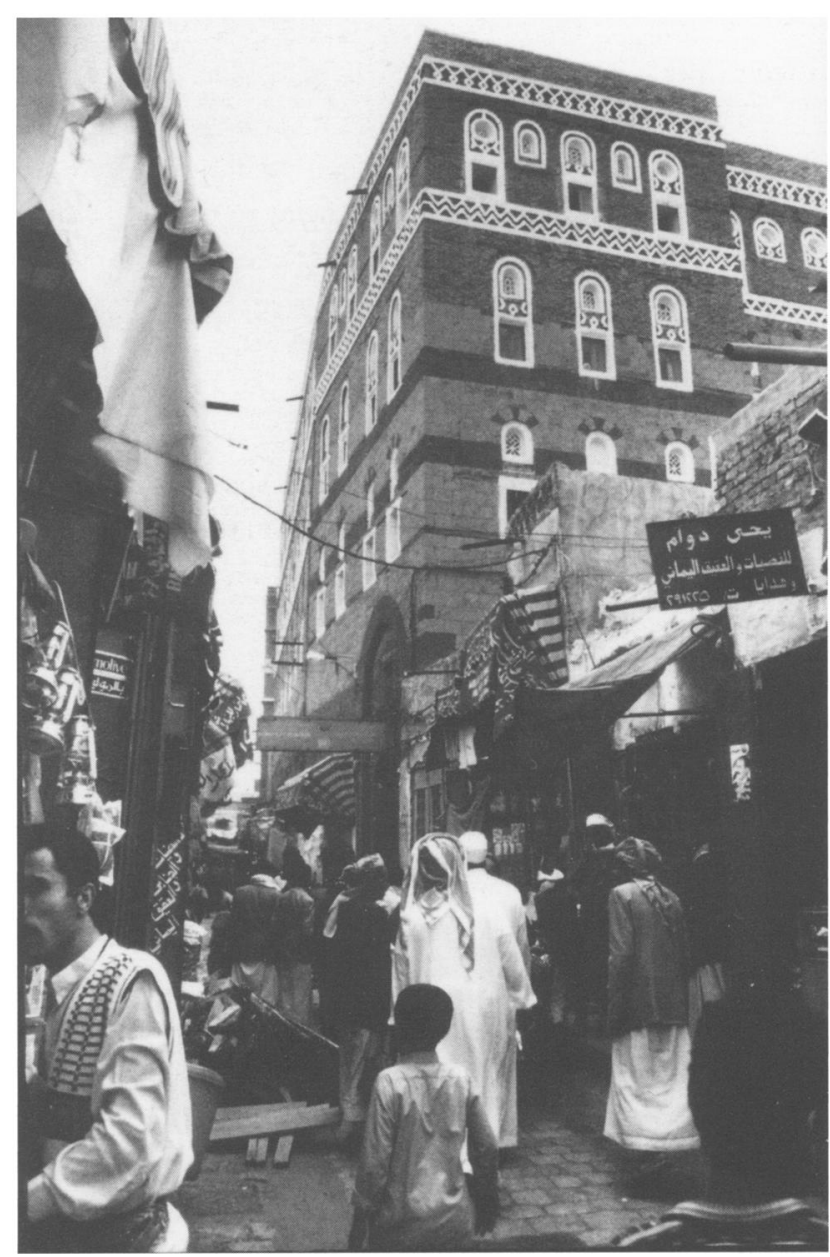

Figure 2 Suq of Sanaa with Samsarat al-Nahhas, an urban khan with upper-level lodging facilities, on the right

and Persian worlds, and on the Arabian peninsula. ${ }^{5}$ Scharabi's framework is helpful, as the terminology for commercial architecture is slippery and misleading. Often a single term can refer to several different kinds of structures with various functions, and standard types go by many different names according to subregion. As basic categories, Scharabi considers the street-level stretch of stores of the retail suq, or market, and two freestanding types that can be found within the sprawl of the commercial area-the covered structure dedicated to specialized merchandise for the retail market without lodgings, often called the qaysariyyah, and the kban, an edifice for bulk wholesale trade with lodging facilities for traveling merchants. Due to its broad nature, Scharabi's framework serves as a starting point for considering the potential range of commercial needs and the possible architectural responses to them.

In most Arab cities, both the qaysariyyah and the urban khan were interspersed within the commercial sprawl of the suq, creating a tightly integrated and spatially unified sector that combined both wholesale and retail activities within its limits. Many examples of the qaysariyyah and urban kban also maintained an exterior façade of retail shops that further tied together the multiple needs of both specialized merchants and everyday shoppers. Similarly, an artisan could use his store in the suq, or within a specific kban or qaysariyyah, for production of goods as well as for sales. The suq of Sanaa offers an illustration of such an integrated fabric, with urban khans distributed along many of the suq's thoroughfares (Figure 2).

Of these commercial components, the khan is of primary interest to the present study, as it is the most important structure in the Arab world that played a role in large-scale international trade. The kban, as a generic type, may take many different names, depending on the region, date of construction, and subtype. Some other lexical possibilities from the Arab world include the wikalab and the funduq. In highland Yemen, the term samsarab is used widely as well. ${ }^{6}$ Despite their diverse names, the structures were used in a fairly consistent manner historically and maintained a standard built form with slight variations. ${ }^{7}$ The term "urban khan" refers to the generalized kind of wholesale public structure that encompasses all of the subtypes mentioned above. It specifies a type found in cities, as distinguished from the rural caravanserais that dotted pilgrimage and trade routes in open areas. While the rural caravanserai and the urban kban share structural and formal qualities, they have different uses. ${ }^{8}$

Different spatial units served different historical functions in the urban khan. A good example is Samsarat alNahhas in Sanaa. ${ }^{9}$ The ground-floor level is subdivided into small stalls, each with doors that can be securely locked, which the merchants rented to store their goods. The small stalls are organized around a central courtyard, which served as a common room for trade, exchange, and discussion; merchants and officials could disseminate news concerning trade from this shared space. Upper levels, subdivided into individual temporary living units and arranged around the courtyard, provided lodgings and basic washrooms suitable for traveling merchants (Figure 3).

In his survey of Arab cities during the Ottoman period, André Raymond evidences the extent to which the urban kban dominated in filling the practical needs of the wholesale trade with this standard commercial model. He states, "The number of caravanserais serves as a definitive index of the amount of economic activity in a city." ${ }^{10}$ According to Raymond, the urban kban governs the level of wholesale trade in an exclusive fashion, thereby serving as an absolute 


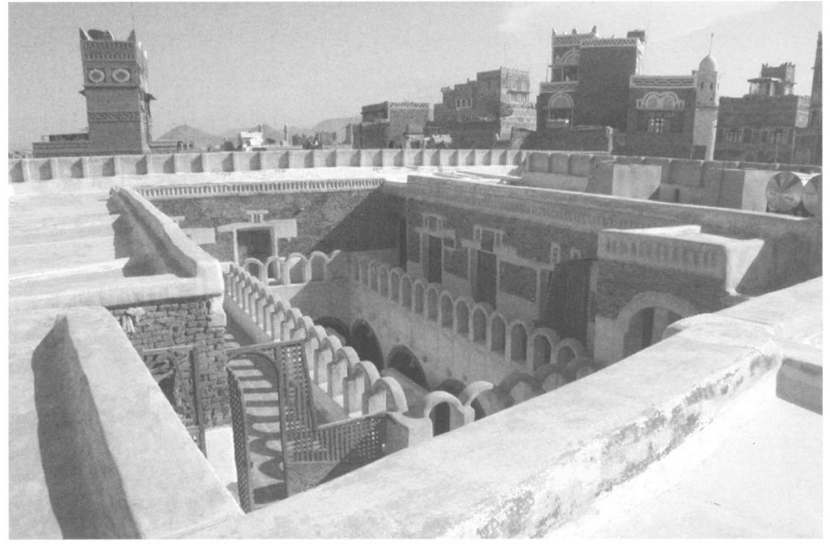

Figure 3 Samsarat al-Nahhas, Sanaa. View from the roof of the upper floors and the doors leading to the individual chambers

indicator of the amount of large-scale commercial activity in a given city.

This organizational model, in which commercial activity is collectively housed in the urban kban, the qaysariyyah, and the suq, takes on spatial specificity in various regional contexts, but always locates the international and high-volume trade in the public sector, linked to the major retail establishments and separate from the private, residential space. Functional roles are tied to formal structures in a distinct way; commercial architecture is associated only with the functions of trade and domestic architecture is understood solely in terms of its residential capacity. My study aims to present an alternative to the paradigm by illustrating a distinct example from eighteenth-century Mocha, where the actual practices of urban merchants collapsed any fixed and rigid understanding of form and function, and the needs of a flourishing trade blurred a firm boundary between the public and private realms.

\section{In Search of the Urban Kban}

In Mocha, a port city devoted to trade and located in a strategic maritime position, one would expect to find an extensive network of urban khans dedicated to commerce. The Dutch historian Cees Brouwer voices this expectation in his encyclopedic monograph on the seventeenth-century city, stating, "the mere existence thereof [of samsarabs or khans] is not mentioned in the sources." ${ }^{11}$ Brouwer assumes that there must have been a number of functional urban khans in Mocha given the volume of trade, but that they simply were not mentioned in the various archival documents he consulted. A review of the most prominent public commercial structures in the city corroborates Brouwer's initial suspicion and veri- fies the conspicuous absence of public buildings that were used by the international wholesale merchant class. ${ }^{12}$

The Customs House was the most important official building in Mocha related to trade. No negotiations would take place there, but rather only official and administrative functions connected to trade and overseen by the governor of the city and other officials, who served as deputies of the Qasimi imam at the port. ${ }^{13}$ Commodities that arrived from overseas and objects destined to be sent abroad would be weighed and cleared for taxes and customs in the Customs House and sometimes stored in it. The space served as the single common room for overseas trade in the city. All merchants needed to pass through it, and they observed daily activity in the interest of their own business. ${ }^{14}$

One public structure in the city was characterized as a caravanserai; however, no major overseas merchant would seek lodging there. It did not function like the urban kban described above, which was meant for use by international merchants. Mocha's caravanserai took on the isolated role of lodging traveling peddlers and pilgrims. ${ }^{15}$ The caravanserai in Mocha, as described by Louis de Grandpré, an eighteenth-century French merchant, was simple and provisional with no luxuries, hardly suitable for upper-class merchants and ship owners. Its single entrance provided access to a four-sided open courtyard with a gallery around the perimeter. Pilgrims en route to Mecca were the primary, albeit temporary, residents of this caravanserai; Grandpré remarked that it "was only full during the pilgrimage season." ${ }^{16}$ Because Mocha was one of the last major stops for pilgrims who came from the south and east, the volume of traffic was intermittent but significant. ${ }^{17}$

Several high-profile figures also stopped by Mocha on the way to the Holy Cities, but they would not have sought housing in this modest caravanserai. In 1071/1660-61, the "daughter of the Mughal Emperor came by sea to Mocha to perform the bajj with goods, servants, subjects, and a retinue. She presented the governor of Mocha, Sayyid Zayd b. 'Ali Jahhaf, with a lot of goods and a great gift." ${ }^{18}$ The author of this description, historian "Abdallah al-Wazir, does not specify that she was the daughter of the Mughal sultan Aurangzeb; regardless, it is clear that she was a high-ranking individual, given the size of her retinue and the fact that she merited mention in this official account. In another instance, in 1079/1668-69, an unnamed Uzbek sultan who held authority over Kashgar-modern-day Kashi, located along western China's silk route-arrived in Mocha on his way to the Holy Cities with an escort of five hundred soldiers and a large retinue. ${ }^{19}$ Although the temporary residences of these important visitors to Mocha were not identified in the texts, such prominent individuals probably would have set up their own camps or stayed at one of the finest 


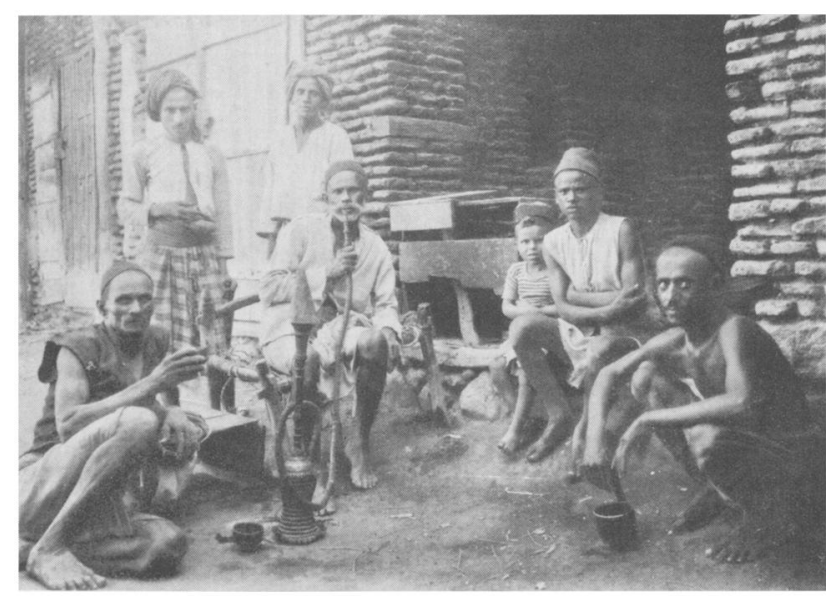

Figure 4 The Suq of Mocha (destroyed)

houses in the city-the governor's palace or one of the merchants' houses-and certainly not in the caravanserai. ${ }^{20}$

Although one may expect that the overseas merchants would operate out of the city suq, this was not the case in Mocha. Just as two classes of pilgrims visited the city, two distinct commercial groups of merchants coexisted there. ${ }^{21}$ Each operated on a different level and occupied a separate urban space for the maintenance of their business activity. The high-volume overseas merchants, tujjar, traded in wholesale quantities of bulk textiles, spices, rice, metals, and aromatics and paid for the goods in Spanish riyals or Mocha dollars. ${ }^{22}$ The retail merchants belonged to a different business class and dealt in small quantities of the above-mentioned import items, as well as other commodities for daily use and consumption. Komasis, the local coin, were used to buy goods from the suq. ${ }^{23}$ Major wholesale merchants would not operate out of this modest suq; its shops were dominated by small-scale businesses that provided everyday goods for the local clientele (Figure 4). It is important to note that there were no urban kbans located within the mercantile region of the suq in Mocha. ${ }^{24}$

Thus, public structures fulfilled none of the daily functions of the overseas trade of Mocha, outside of customs clearance. While one may expect to find urban kbans established for the purposes of commerce, the major overseas merchants at Mocha did not conduct their business in public structures, nor did they use such public buildings for lodging.

\section{The Merchant's House}

The historical sources from the first half of the eighteenth century consistently describe trade activity, meetings, and storage located within the houses and residential complexes of the merchants-the primary center for negotiations among the major merchants who participated in overseas trade. The house took on the multiple functions of warehouse, trade establishment, and residence. Some merchants would rent extra warehouse space to accommodate an overflow of goods, but most of the time a single house would serve several uses.

The contemporary Arabic texts are silent on the everyday functional details of commercial interaction, but a close analysis of them suggests this mode of organization. None of the sources indicate the presence of public structures for the facilitation of trade in Mocha, not even in passing reference, whereas they often mention the samsarabs and kbans of Sanaa or other highland cities. Furthermore, one anonymous Yemeni account refers to the house that served as the residential trading establishment of the French East India Company in Mocha as a dukkan, a small retail shop. ${ }^{25}$ This label, albeit imprecise, suggests the commercial and residential nature of the merchant's house in Mocha. Apparently, the historical reference, probably transmitted via a highland historian, indicates the lack of a specific term for such a structure that encompassed both public and private roles, a functional duality that was not observed in other Yemeni highland cities.

The European sources, in which everyday references to trade activity are much more abundant, provide the clearest information. Through more than twenty years of daily documentation of the city in the eighteenth century, the Dutch describe this domestic localization of commerce in all their records of transactions with both local and other foreign merchants. ${ }^{26} \mathrm{~A}$ few entries serve as examples. On 5 January 1706, some Bohrah merchants from Ahmedabad, in northwest India, entered the Dutch house asking the VOC representatives for help in getting a sum of confiscated money returned to them. ${ }^{27}$ On 8 January of the same year, the broker of the city's governor visited the Dutch at their house to tell them that the governor was interested in purchasing some goods. ${ }^{28}$ On 15 April 1706, a group of Baniyan brokers paid a visit to the Dutch residence to complain about the poor quality of the pepper that they bought from them, which was mixed with dirt. ${ }^{29}$ The next day, the Dutch went to the house of the Baniyans to take account of how much dirt was mixed in with the shipment. On another occasion, the Dutch chief resident stopped by the home of one of the leading merchants of the city, Qasim Turbati, and found two other major Muslim merchants there with him. ${ }^{30}$ From a continuous reading of these and other accounts, it is clear that the residence served as the locus of all negotiations, trade interaction, and storage of goods, not to mention lodging and all social exchanges. 
All important transactions took place in the residences of the merchants, for example, in the house of the often mentioned Turbati, who frequently entertained the favor of the imam and his officials, or Muhammad Yasin, another prominent Persian merchant at the port. The governor, whose personal success was inextricably linked to the overall success of trade, would have objects brought to him for inspection at his palace. ${ }^{31}$ Meetings among the major Muslim merchants of the city (including a diverse group of Arabs, Persians, and Indians) such as the Surati 'Abd al-Ghafur or Turbati would take place at their houses. ${ }^{32}$ The accounts include less specific passing references to houses that accommodated other groups of traveling merchants. Those from Masqat kept at least one house in the city, but probably more, judging from the number of merchants who would have been in residence at the port during the high trade season. Those from Kung, on the Persian coast of the gulf, also had at least one residence in Mocha. ${ }^{33}$ Although the sources do not mention a house of the merchants from Basra or Bandar 'Abbas, there must have been at least one for each of these groups; there were probably many more, as several ships from those cities called at the port each season.

Domestic localization of trade cut through the strata of the overseas merchant class. The Europeans conformed to this practice: they visited merchants at their homes (or sent their brokers) and welcomed other merchants into their own residences on a daily basis. The Baniyan brokers, too, conducted business-including negotiations, storage, and lodging-out of their homes. ${ }^{34}$ The residents of many Baniyan households would work together, as in the household of Vira, who, with his many sons, served as the primary broker to all Europeans in the first part of the eighteenth century. It is well documented that Baniyan women never traveled with their male counterparts to participate in this émigré lifestyle, an important point that allowed for their houses to serve as business facilities with no conflict with family privacy. The Baniyans even lodged foreign merchants in their own residences temporarily, as Vira did on one occasion. ${ }^{35}$

The inadequacies of terminology complicate our understanding of the merchant's house as the site of trade in this port city. Modern historians often use the word "factory" to describe the early modern European trading establishments in Indian Ocean cities, and it is indeed applied to Mocha. It is, however, misleading in this context because "factory" seems to indicate a specific type of structure that would have looked and functioned differently than a normal house, as was the case in other Indian Ocean cities. The Europeans in Mocha had no factory in that sense. They rented their residences and used them in a multidimensional manner as their trading establishments. This practice followed the dominant mode of conducting trade in Mocha. European residences did not carry any visual or structural markers to distinguish them from other stone-and-brick houses in the city, except for their flags, a right that the imam had granted them in their trade treaties. In Mocha, the Europeans had their "factories," or "comptoirs," based in their residences, and did not maintain any other official structures for the trade.

Several of the larger houses were enclosed in walled areas that also included animal pens and perhaps extra warehouse space, thus constituting complexes. The historical texts are misleading on the subject because they seem to suggest that several distinct structures fulfilled the various purposes associated with trade. For example, the Dutch might comment about their "warehouse," then in another instance mention their "residence," which implies two separate structures. All such functions, however, were housed in one building or complex, and the scattered references relate to parts of the house rather than separate edifices.

\section{The Plan and Layout of the Merchant's House}

While no houses from eighteenth-century Mocha stand today, residences that date to a later period may shed light on the structural dimensions of such an urban commercial organization that has not been considered in other Arab cities. Of the houses that were surveyed in Mocha in 2000, none can be proven to date to a period before the nineteenth century. ${ }^{36}$ However, their layout and structure serve as the only remaining data that can illuminate the organization of earlier homes that have not survived. Further, all of the later houses display consistent features, many of which are corroborated in early texts, thereby making a strong case for a stable tradition of building that probably dated to earlier decades as well. An examination of the existing domiciles in the city demonstrates that historic commercial transactions most likely took place in them.

The typical nineteenth- and early-twentieth-century house in Mocha exhibits several standard attributes. ${ }^{37}$ The whitewashed stone-and-brick merchant's house in Mocha diverged significantly from the traditional courtyard model of the Mediterranean and from the ubiquitous Yemeni tower house. ${ }^{38}$ The Mocha house rose two to four stories high and was elaborately ornamented on its front façade, with carved wooden doors and projecting windows, as illustrated in historical photographs (Figure 5). These merchants' houses stood distinctly apart from the large conglomeration of reed-and-mud houses that made up the majority of the intramural and extramural settlement in the 


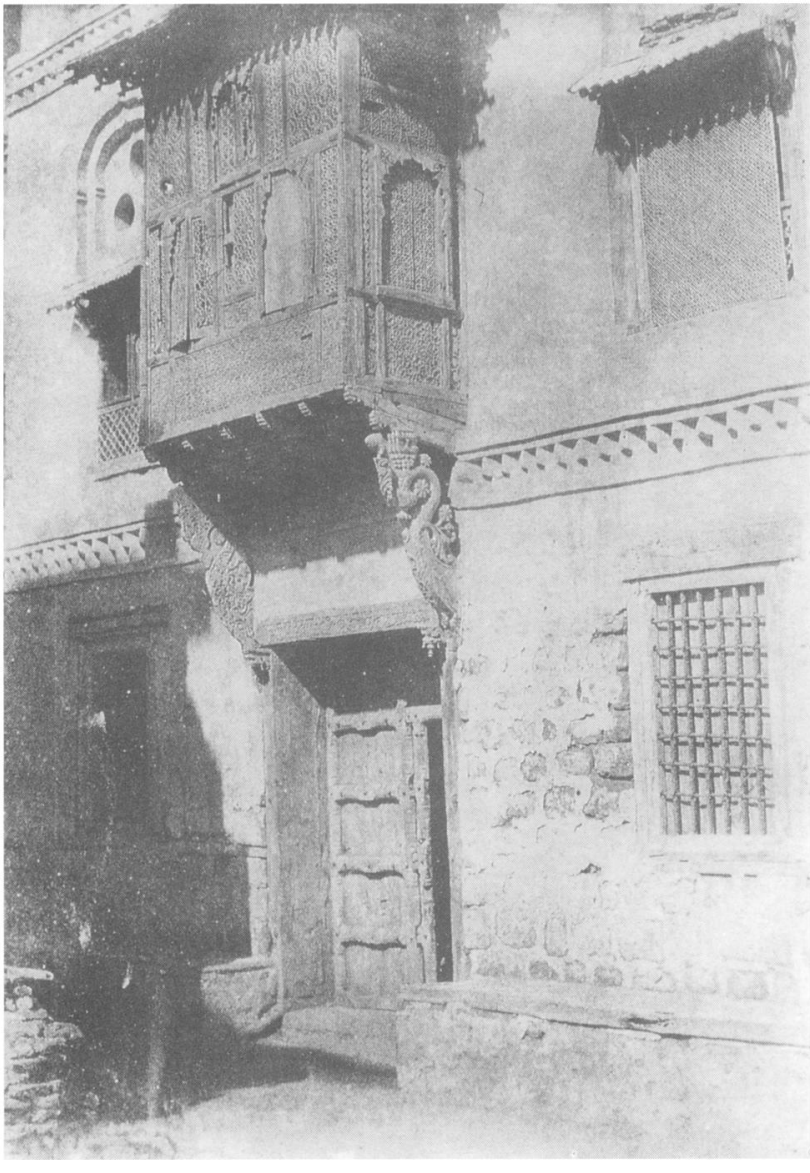

Figure 5 A nineteenth-century house in Mocha (destroyed)

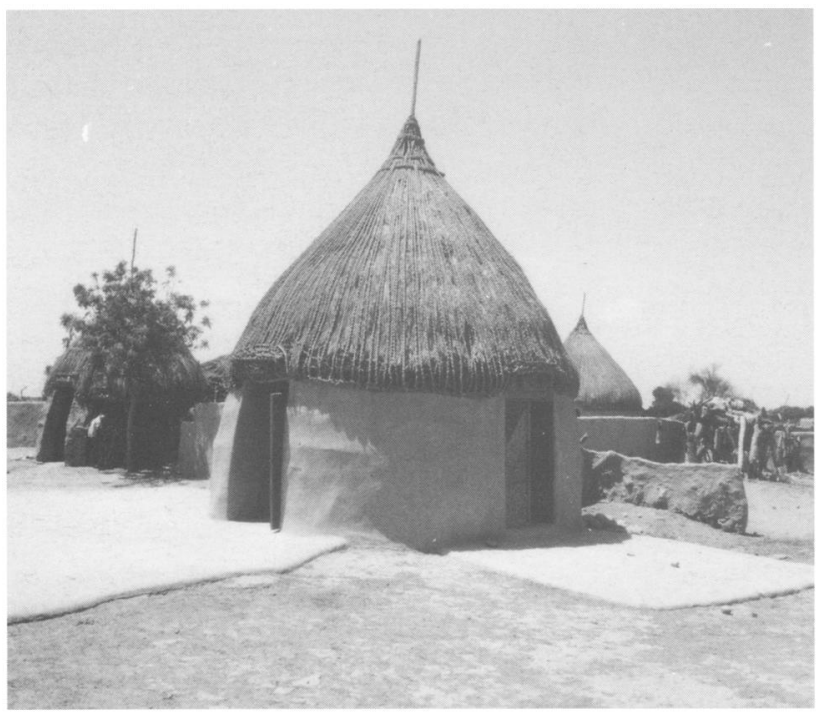

Figure 6 A reed-and-mud house in the village of al-Risas, Yemen. This type used to be dominant in the southern Red Sea coastal plain of Yemen. area (Figure 6). The whole ground floor served as the warehouse; it had no large windows and was easily accessible. All the houses surveyed had more than one entrance to the ground-floor space, which was subdivided, allowing for a variety of areas that could facilitate trade activity. The family or other residents used the upper floors, including the roof, for cooking, eating, and sleeping, as described by Grandpré in $1789 .{ }^{39}$ Although there was no interior courtyard, an open-air light well would bring natural light and cool breezes into the enclosed rooms on the upper levels.

Bayt al-Mahfadi, a house that probably dates to the mid- or late nineteenth century, illustrates how the ground floor could be divided up as a storage space (Figure 7). ${ }^{40}$ The complex division of the ground floor of Bayt al-Mahfadi suggests that multiple functions may have been served there, most of them public rather than private and family oriented. The main entrance is on the north side and is emphasized by the principal rawshan, or projecting wooden window, above it (Figure 8). All the house's inhabitants use this door for access to most of the spaces. When he or she passes through the primary northern entrance, he or she may ascend directly to the upper floors or enter one of two lateral storage spaces (indicated on the plan in Figure 7 as $1 \mathrm{~A}$ and $1 \mathrm{~B}$ ) or the main central storage area with its subsidiary storage spaces $(1 \mathrm{E}, 1 \mathrm{D})$.

Another entrance to the house is located on the southern end (Figure 9); it leads to the small chamber marked $1 \mathrm{~F}$ in Figure 7. Potential buyers and other merchants could use the secondary entrance to gain access to the storage areas without disturbing family members. The merchants could discuss the details of their transactions in the chamber, which is well fenestrated and connected to the larger storage area. ${ }^{41}$ Although small, the room certainly could have accommodated ceremonies related to the execution of trade transactions. Sources describe a traditional elaborate ritual that accompanied any visit and consisted of sprinkling rosewater, burning aromatics, and the offering of coffee. From this room, the merchants had immediate access to the main storage area, where they could examine goods in person or pick up their merchandise. Room 1C, located at the mezzanine level and entered through the front door, also may have served as a more public meeting place. With its many windows and larger size, it could have accommodated more social functions, again allowing nonfamily males to enter the house without inconveniencing family members above.

Generally, design of Arab houses must integrate consideration of gender segregation and patterns of family visibility as major concerns, and a dual-entry system is a standard solution in other Arab house types as well as that 

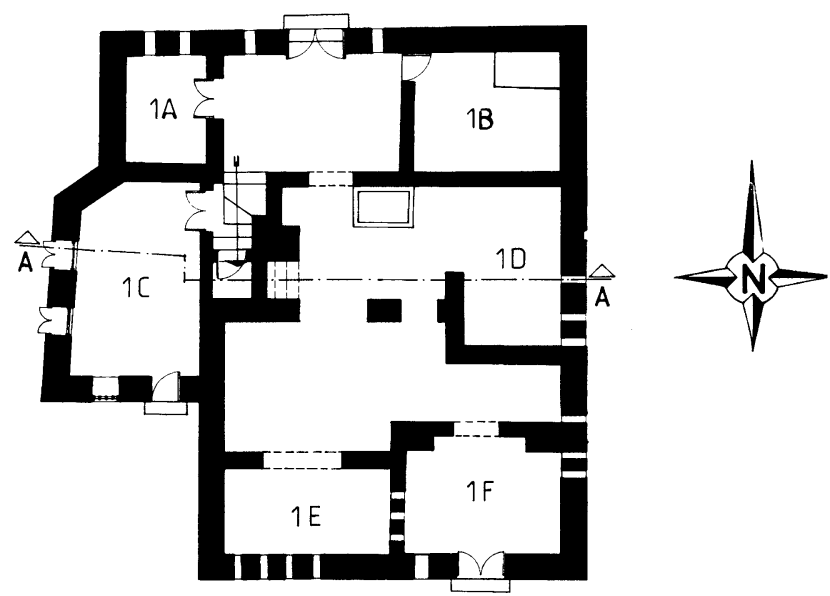

Figure 7 Bayt al-Mahfadi, Mocha, nineteenth century. Ground-floor plan

Figure 8 Bayt al-Mahfadi, Mocha, north façade. Note the contemporary restoration in cement carried out by the al-Mahfadi family in the 1990s.

represented by Bayt al-Mahfadi. ${ }^{42}$ However, in those cases, the primary door serves as the men's entrance, and as the more public entry, and the secondary door, located off a main street, is for family use and often leads directly to the separate female quarters (and is discussed below, in the cases of Jiddah and Sawakin). In Mocha, the dual-entry system channeled mixed traffic through the front of the house, and the secondary entrance serviced commercial interaction or visitors who called for other business purposes.

Rather than a lateral system of segregation, a vertical organization seems to have dominated in Mocha. ${ }^{43}$ The upper stories of the house, inhabited and used collectively by the family, could be securely closed off from the lower level by a door at the top of the stairs. It is possible that this upper door, rather than the front entrance to the house, acted as the true threshold to the domestic space. Today the current inhabitants enter and leave via the front door, which is kept unlocked and open. They lock only the upper door, which is unornamented and smaller, but seems to fulfill a more central function as a social boundary.

Certainly, not all merchants conducted their trade transactions in the same way. In eighteenth-century Mocha, many of the residences of the traveling merchant class only housed men, who made up the majority of crew members and merchants at the port during the trade season.${ }^{44}$ Europeans, who rented houses with their fellow male merchants, described how they would invite other merchants to the
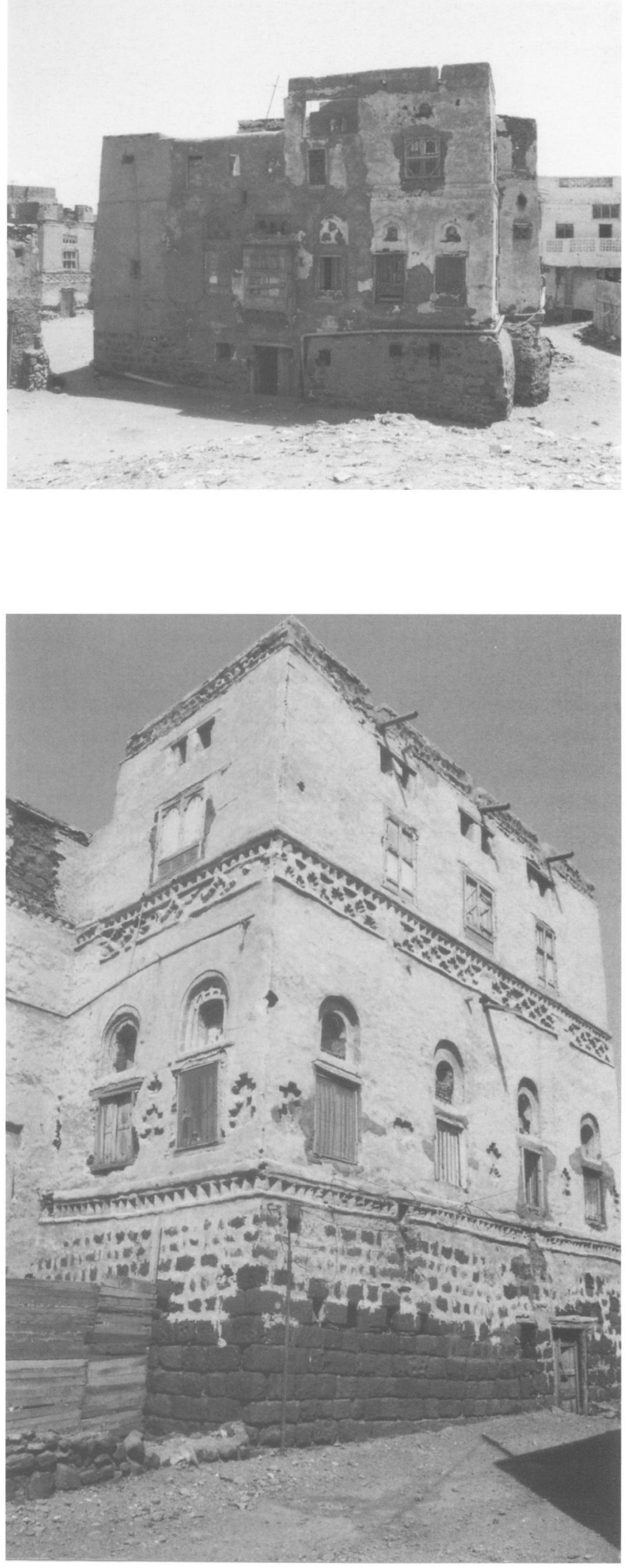

Figure 9 Bayt al-Mahfadi, south side. The small door (located in the lower right corner of the photograph) leads to the back chamber and the storage areas. 
upper levels of their houses to discuss business, without any intrusion into family space. ${ }^{45}$ Other European merchants wrote with delight about being invited into the upper quarters of Arab residences and catching glimpses of the women of the house. ${ }^{46}$ However, the layout of the houses, such as Bayt al-Mahfadi, allowed for a process of selective access to family-oriented areas, if the residents so desired. For example, Turbati was not a native to the city of Mocha and brought his family to live with him there. In a case such as his, the layout of the house, where the upper floors could be sealed off from the more public spaces of the lower level, provided ample room for the family to use without entering the space of negotiation or having to encounter strangers within the domestic sphere.

Some overseas merchants maintained separate storage facilities in addition to those in their main residences, and the imam, in his faraway highland capital, kept a storehouse in Mocha to accommodate the bulk of his trade, which he carried out by way of an agent in the city. Also, the groundfloor storage areas of Mocha houses can be considered independent from the upper residence levels. As in the urban khans, many of the ground-floor storage spaces were composed of units that had their own lockable doors, suggesting that whole areas could be segmented and potentially rented out to a merchant who did not also reside there. ${ }^{+7}$ Often these supplementary spaces were rented out to store extra goods, especially during peak season. (On 12 July 1730, a private English merchant referred to as Mr. Harnett rented "three great houses including their warehouses" in order to store all of the goods for the winter, which he had brought to Mocha to be sold without success. ${ }^{+8}$ In one instance, the Dutch rented an additional small warehouse to store their goods while the ground-floor warehouse inside their residence was being repaired. ${ }^{+9}$ This secondary space may have been a dedicated storage structure or a part of a house.

\section{Continuities and Divergences}

Thus, it was essential for major merchants to have their own houses in order to carry out trade in the locally dominant manner. This organization differs greatly from the Arab urban trade model presented above, in which activity was based in public structures of trade and travel that were located within the commercial sector of the city, like the urban kban. Other Arab cities present examples in which private domestic space and public commercial needs overlap, but none in which public structures are excluded from a role in commercial negotiations. ${ }^{50}$ For instance, in Jiddah, a coastal city north of Mocha, the ground floor of the mer- chants' tower houses also served as the locus of commercial negotiations and storage. ${ }^{51}$ However, here the dual-entry system functioned differently (the secondary entrance was used by the family), and these houses, along with an articulated network of urban kbans, served the commercial needs of merchants.

Cairo provides an example of a different type of urban structure, the $r a b$ ', a housing complex with apartments leased to traveling merchants and individual families for long-term residence. ${ }^{52}$ The $r a b$ ' was rarely self-contained, but was usually located above a public, income-generating structure, usually a wikalab or a row of retail shops, within an economically vibrant commercial sector of town. ${ }^{53}$ It is a unique type of collective housing structure in the Arab world that functioned similarly to a modern apartment building and was a spatial and economic response to the growing density of Cairo. Inhabitants lived in their own unit with their own kitchen and latrine, but shared access to the residential part of the building and certain other spaces. Unlike the Mocha house, the rab' was clearly public in its role, related more closely in form and organization to the wikalah than the private home. However, with their spaces that grafted the needs of public and private realms, the Jiddah tower house and the $r a b$ ' illustrate the potential for divergence from typical residential forms and their accepted functions in other Arab commercial centers.

It is clear that the organization of trade in urban Mocha differed markedly both from the established commercial patterns in the Arab eastern Mediterranean and North Africa and from those in nearby inland Yemeni cities such as Sanaa. Mocha diverged so significantly from these local and distant Arab counterparts because it was participating in a maritime world and was thus fully entrenched in another system. Many of the merchants who frequented the port were accustomed to a different mode of commercial interaction. Therefore, Mocha's spatial organization and urban trade network should be examined in the context of its maritime setting and relationships to a world far beyond its regional boundaries and cultural milieu.

Examples from the Indian Ocean and neighboring Red Sea regions provide a maritime framework for the localization of trade functions in the Mocha house. Regarding the trading practices of Swahili coastal cities, James de Vere Allen comments:

In some respects the miji [Swahili coast trading cities] were typically Muslim towns, but in others they did not exactly conform. They had, for instance ... no bazaar or covered market. . . . Nor did the Swahili have caravanserai or khans (funduqs) with -in an urban context-space for itinerant merchants to stow their 
wares. .. . This suggests that, in the absence of a bazaar, many houses doubled as shops for goods of at least the more important visitors. ${ }^{54}$

The Swahili coast thus presents a larger context for Mocha's urban trade structure outside of the Arab realm but within the greater Islamic maritime world.

An example from an Arab city located near Mocha, but across the Red Sea, further illustrates coastal continuities. The historic merchant's house of Sawakin on the western coast of Sudan functioned similarly to the merchant's house in Mocha with a full-service commercial ground floor for storage and meetings. ${ }^{55}$ However, here the dual-entry system functioned as it did in Jiddah, where the back entrance enabled the family to ascend to the upper floors, which constituted the domestic sphere, and the front entrance fulfilled a more public function. ${ }^{56}$ In the past, preceding the establishment of modern public institutions such as banks and company buildings, the merchant's house in Sawakin serviced all types of wholesale overseas trade negotiation and activity in the absence of public structures. Underlining this fact, the wikalab of the city was built in 1881 by an Egyptian merchant, who was obviously transplanting ideas about trade that were native to his homeland. ${ }^{57}$ In his monograph on the city, Jean-Pierre Greenlaw emphasizes that the new wikalab of the late nineteenth century did not replace a previous trade structure, but rather the $n u z l$, the open space where the camels would unload their goods, and hence it was a new structural concept in Sawakin.

The haveli house was the domestic locus of most professional activity in regional urban centers of Gujarat, India, with a layout that allowed the family-oriented spaces in the back of the house to remain separate and undisturbed by events that took place on multiple stories in the front of the house, which accommodated more public activity, including business and social interactions. ${ }^{58} \mathrm{~V}$. S. Pramar writes:

Although the Gujarati town was known for its extensive commercial activities, there was no provision for any permanent market place and commercial buildings, no place of adjudication, no place for public assembly even of merchants, no town hall, and almost no inns. The Muslim sarai existed only in a few major towns and was obviously an imported concept; the Hindus had no equivalent. The reason for this lies in the nature of Hindu commerce and manufacture which were carried out strictly within the domestic sphere. ${ }^{59}$

These three examples provide evidence of a system for the domestic localization of trade activity that spanned continents and linked coasts. In each of the Indian Ocean and
Red Sea locales, coastal house types accommodated trade in the absence of a network of public commercial structures. Although they all participated in a maritime social system of trade that was situated in the domestic sphere, no two of the house plans are identical in their organization. The Swahili coast house is single storied or double storied, with a division of space along parallel axes. The Sawakin house distinctly resembles the Mocha house, although the system of entry differs, as discussed above. The Haveli house is multistoried, with a gallery around a square courtyard as the basic building block. Each house type represents a separate structural and formal mode of handling both public and private activities in the merchant's house, while corresponding to the maritime system that situated public activity within the limits of the private house.

\section{The Spatial Logic of Trade}

As boats entered the harbor in eighteenth-century Mocha, their passengers and crews would see rows of merchants' houses in the distance, which lent the city the effect of a shining white façade. Mixed within that skyline, a few tall, whitewashed minarets served as navigation points for the sailors. The boats would pass two towers, Qal'at 'Abd alRauf and Qal'at al-Tayyar, each at one end of a crescentshaped promontory. The jetty extended from the center of the city's coastline and served the small, lighter boats that would bring crew members and goods from the ships that were anchored offshore. Originally surrounded by a stoneand-mud wall pierced by five gates, the city was defensible from both land and sea.

Today most of these landmarks, including the wall, its gates, the towers, and some of the mosques, have collapsed. However, textual sources and historical prints and photographs help us reconstruct the former shape of the city (see Figure 13). It appears that the eighteenth-century city did not have a single public core, but rather was organized according to a dual system that distinguished between the needs of the international community of wholesale merchants and the local residents.

Mocha's inland southeastern quadrant functioned as the original center before the Ottomans arrived in the sixteenth century. The famous Sufi scholar and saint Shaykh Shams al-Din 'Ali b. 'Umar al-Qirshi al-Shadhili lived and taught in Mocha and died there in $818 / 1415-16 .{ }^{60} \mathrm{~A}$ focused religious precinct developed around his mosque (Figure 10), including the Great Mosque (Figure 11), which was destroyed during the Turkish-Italian War of 1911-12, and the small Mosque of Sayyidah Zaynab, of which nothing remains today but the minaret (see Figure 1). Numer- 


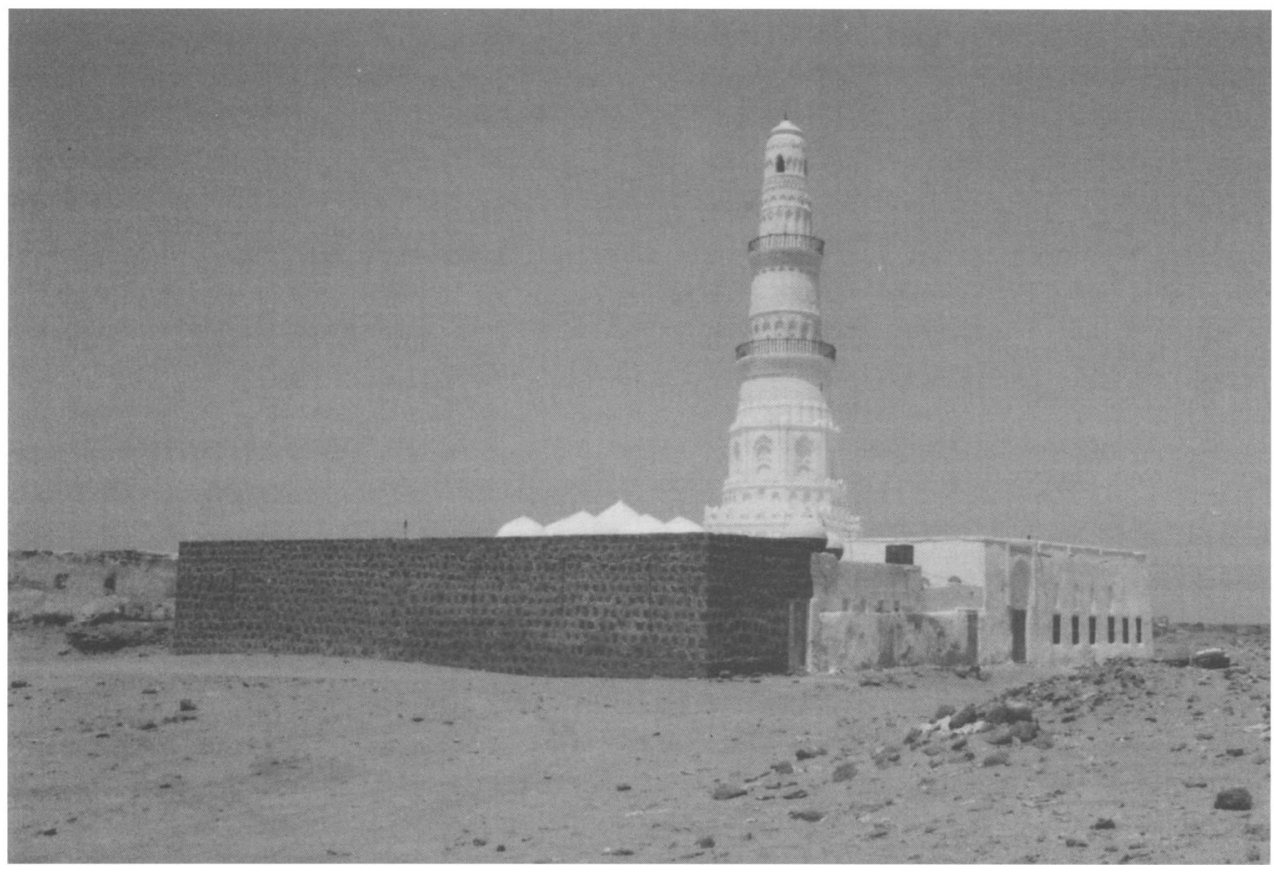

Figure 10 Mosque of al-

Shadhili, Mocha, fifteenth century. The photograph shows the modern expansion in stone to the west of the historic mosque.

ous tombs and an intramural cemetery also added to the sanctity and historical importance of the eastern sector, including the Tomb of al-Shadhili right next to the mosque, the Tomb of al-Sadiq, one of al-Shadhili's sons, and the Tomb of Hatim al-Ahdal, a famous Yemeni poet who resided in the city and died there in 1013/1604. ${ }^{61}$

Around and between these major religious structures and plots was the public commercial zone, with an extended, local retail market that included many shops and coffeehouses built of brick. ${ }^{62}$ Although this suq was destroyed, a single memory of its form is captured in an early-twentieth-century photograph (see Figure 4). Houses were clustered around the main core. Presumably many were made of reed and mud, while some of the more prominent ones were constructed of stone and whitewashed brick. At this time, fishermen dominated the shore, and no fortified walls protected the city's inhabitants, although small forts by the sea may have served as surveillance posts.

Due to Mocha's strategic location, the Ottomans used it as an important base for the maintenance of their Yemeni province and installed administrative facilities there by the mid-sixteenth century, as is proven by a coin minted in the port of Mocha and dated 970/1562-63. ${ }^{63}$ With their interest in maintaining commerce and communication with the rest of the Ottoman world, they focused their official functions related to trade, travel, and administration along the western shore of the city, a sector that had not been developed previously (Figure 12). The buildings they erected along the coast included the governor's house, the Customs House, and the caravanserai. The governor used the neighboring city square for military lineups and exhibitions and his soldiers would often joust there to honor a guest or celebrate an event. Jean de la Roque described how the city's soldiers would wait in the square to escort the governor to the mosque every day at noon with flags and music. ${ }^{64}$ Another important structure, the prison, established presumably by the Ottomans, took its place along the waterside to the north of the governor's house. Contemporary sources mention the prison often in daily accounts, as the governor would place prominent members of the community (including merchants and officials) in jail temporarily to forcibly procure loans and advance payment of tolls. Many of the whitewashed stone-and-brick merchants' houses were located along this part of the shoreline and further added to the everyday functional operations of commercial life that dominated the coastal strip, which was for merchants a convenient and fitting location in which to live and carry out trade. Bayt al-Mahfadi, a later addition, is located in the southern sector of this shoreline region.

Although the urban order described above was established by the Ottomans, the Qasimi imams' officials maintained the spatial dimensions of the administrative structure that was already set up after the Ottoman expulsion of 1636. Hence, the public character of the eighteenth-century city was not unified, but rather located in two distinct and separate zones. In essence, the visitor who entered the city by 


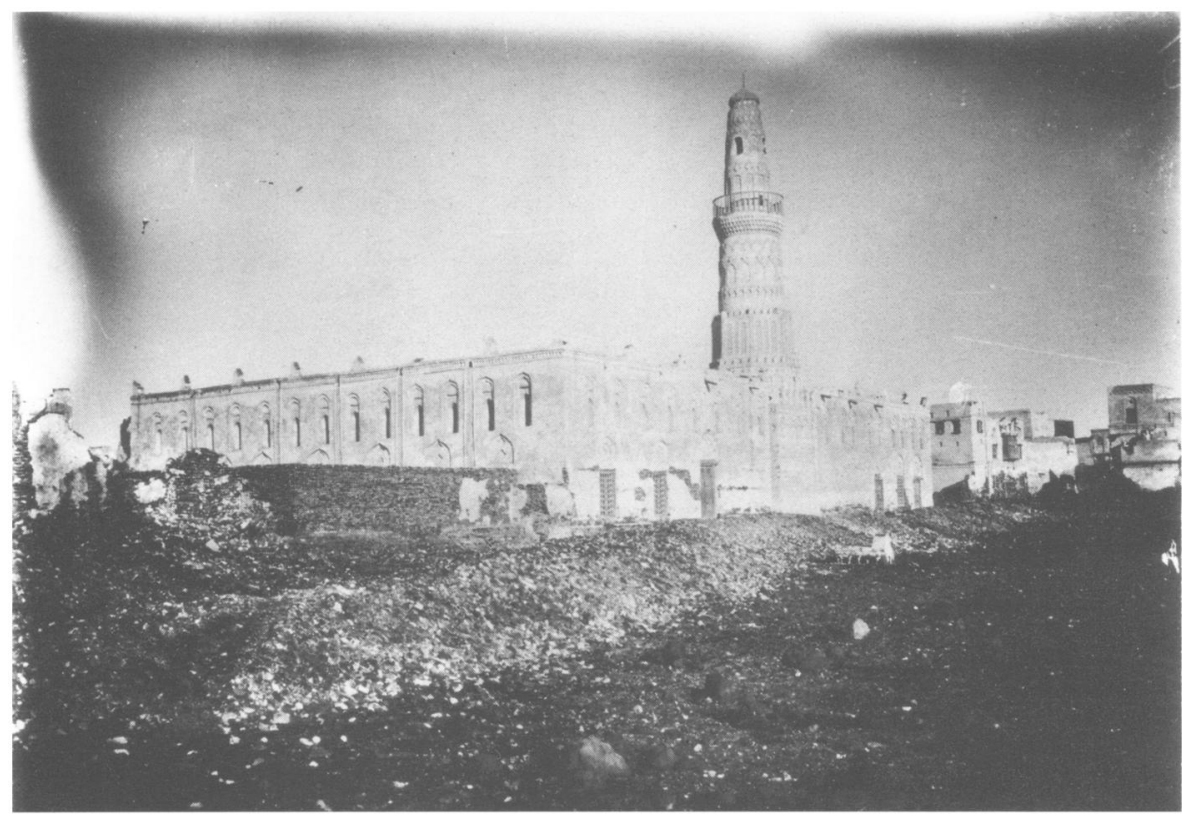

Figure 11 Great Mosque of Mocha (destroyed early twentieth century)

Figure 12 View of Mocha's shoreline from the southern promontory

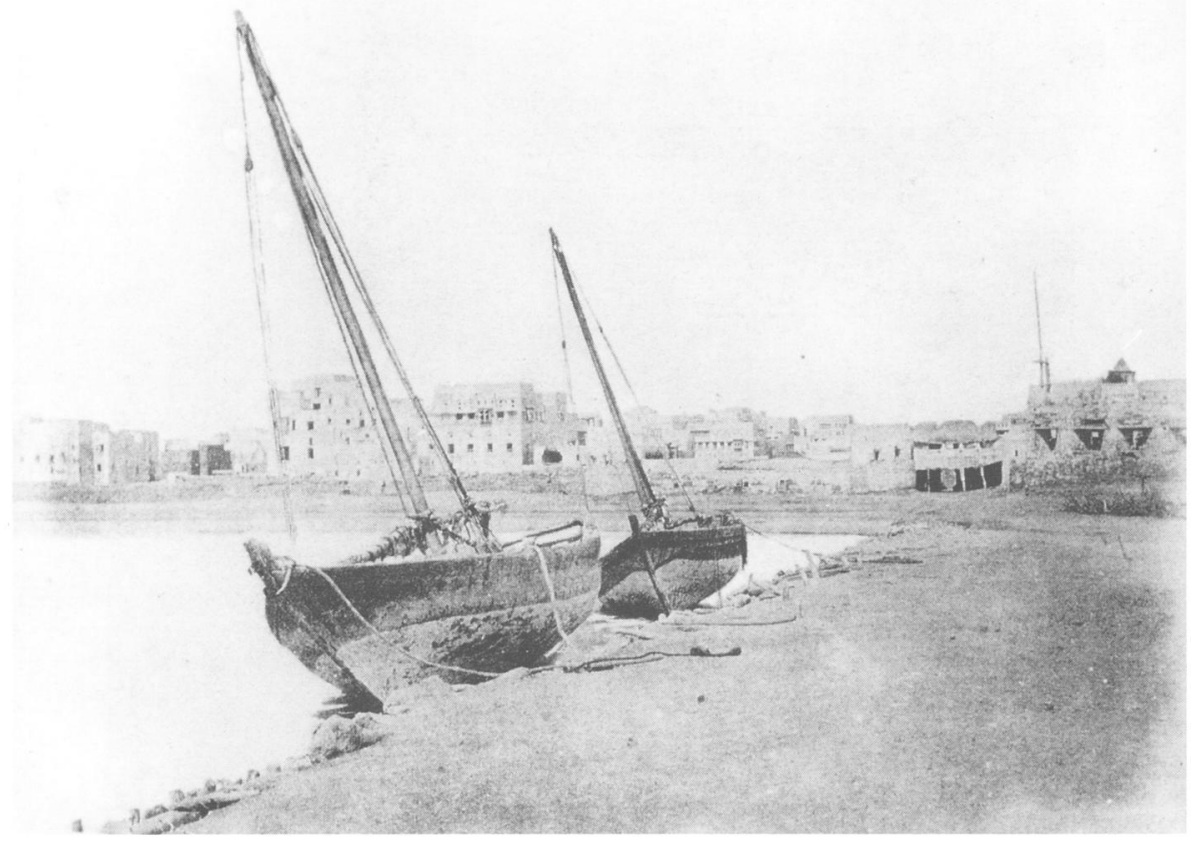

way of the eastern gate, from inland Yemen, would experience Mocha as a typical town of the Tihamah plain, with its brick, single-story suq, houses of reed and mud, and major religious establishments in whitewashed stone and brick. However, the traveler who came by boat would encounter the city as a maritime center, with all the visual and structural markers of its international character, including the towering merchants' houses with projecting windows of imported wood and the administrative monuments of a port city, such as the Customs House and the lofty governor's palace. While one may expect to find an integrated commercial sector that combined wholesale and retail, Mocha's organization reveals a clear spatial distinction between the two worlds (Figure 13). The city, which evolved gradually as a response to the growing needs of trade, posited a unique layout in which the overseas world of commerce was divided from that of the local Yemeni community.

In this essay, I have presented an example for trade interaction in the city of Mocha, that is, the private merchant's house, which served as the locus of trade activities in 


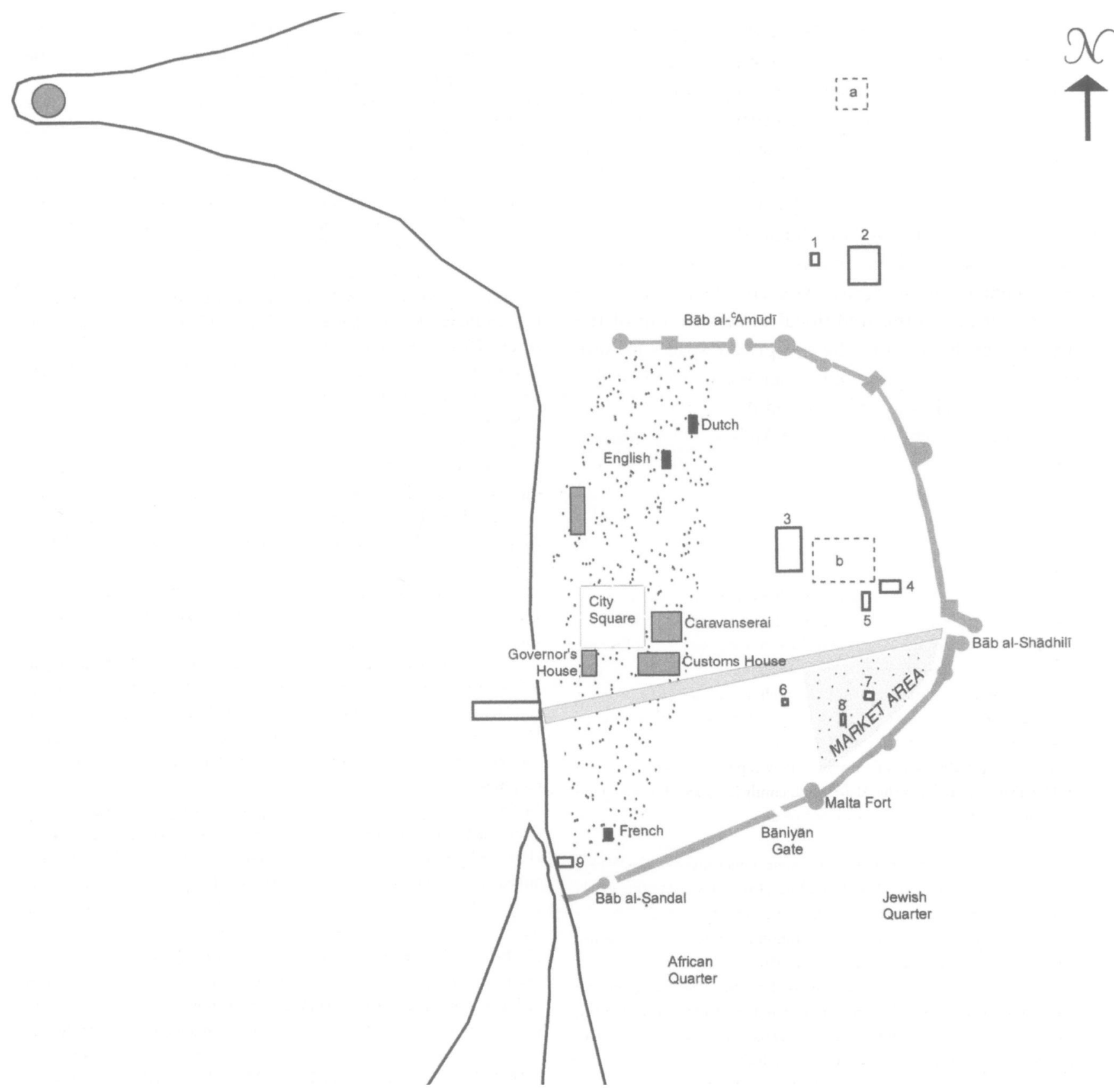

Figure 13 Reconstructed map showing the location of major structures in early eighteenth-century Mocha. The map was produced by the author based on a number of historical maps and textual sources. It is not drawn to scale. Religious structures: 1. Tomb of al-'Amudi; 2. AlMusalla; 3. The Great Mosque; 4. Mosque of al-Shadhili; 5. Tomb of al-Shadhili; 6. Tomb of Hatim al-Ahdal; 7. Tomb of al-Sadiq; 8. Mosque of Sayyidah Zaynab; 9. Mosque of al-Sandal. Cemeteries: a. European cemetery; b. Cemetery of al-Shadhili and the Great Mosque 
the absence of public spaces dedicated to such functions. The commercial practices observed in other eastern Mediterranean, North African, and inland Yemeni urban centers pose a scheme of commercial organization where wholesale trade takes place in the urban kban, which was structurally distinct but spatially related to the retail sectors of the city. Mocha constitutes a case that relates to the system found in the extended Indian Ocean and Red Sea regions. The city maintained a bifurcated commercial realm that represented wholesale international trade activity and retail exchange and local life. As such, this new example adds complexity to the traditional understanding of the sharp division between public and private spaces in Arab cities and provides a precedent as an alternative model of the domestic localization of trade and the functional differentiation of commerce in a historic Arab port city devoted to trade.

\section{Notes}

Versions of this paper were presented at the Historians of Islamic Art Majlis, Philadelphia, 24 February 2002, and at the International Conference on Cultural Exchange in the Indian Ocean World, University of California, Los Angeles, 6 April 2002. I would like to thank the audiences and conference commentators for their responses, as well as Charles Burroughs for his comments on an earlier draft of the paper. I gratefully acknowledge grants from the American Institute for Yemeni Studies for fieldwork in Yemen in 1996 and 2002 and a Fulbright Fellowship for fieldwork in Yemen in 2000. I also wish to thank the Al-Mahfadi family in Mocha for giving me permission to photograph and draw plans of their house.

1. Not only are the western versions of the name numerous-Mocha, Moka, Mokka, and others-but the Arabic spelling also varies. Sometimes it is spelled with a final bamza and sometimes the bamza is omitted. In this paper, I use the accepted English transliteration for Arabic words that are employed in the English language (such as Mocha, Sanaa, and Basra). In the text, diacriticals are not marked; ' is used for the letter 'ayn, and the bamza is not distinguished. When sources cited use Common Era dates, only Common Era dates are given. When bijri dates are used, the bijri date is followed by a slash and its Common Era equivalent.

2. The port of Mocha still functions today; it was rebuilt to the south of the historic city in the mid-twentieth century. Accordingly, the main core of the city has migrated to the south.

3. In this essay, I refer to these diaries, or Dag Registers, by their catalogue numbers, beginning with "VOC" and followed by a four-digit number and often the date of the entry.

4. These trade documents should be set apart clearly from the travel narratives from the same period that I also consulted. While travel writers frequently noted down their observations casually based on short stays in foreign locations, the trade documents were recorded by official scribes who often kept their overseas posts for several years.

5. Mohamed Scharabi, Der Bazar. Das traditionelle Stadtzentrum im Naben Osten und seine Handelseinrightungen (Tübingen, 1985). In each case, Scharabi gives the terms for Turkish and Persian equivalents. For the purposes of this essay, I will refer to the relevant Arabic terms only. Aside from
Scharabi's encyclopedic work, most of the other studies of Arab commercial sectors focus on Cairo, for instance, Nelly Hanna, An Urban History of Bulaq in the Mamluk and Ottoman Periods (Supplément aux Annales Islamologiques, Cabier no. 3) (Cairo, 1983), and Sylvie Denoix, Jean-Charles Depaule, and Michel Tuchscherer, eds., Le Khan al-Khalili et ses environs. Un Centre commercial et artisanal au Caire du XIIIe au XXe siècle, Études urbaines 4/1 (Cairo, 1999).

6. The term samsarab is used along with the term khan in Yemen. However, some samsarabs function like the urban kban, with lodging cells above, and others fulfill the role of the qaysarriyah, without lodging, although there is no distinction in terminology. Samsarah, from the word samsar, or broker, appears to be relatively new, perhaps coming into use during the first Ottoman occupation. Ronald Lewcock, "The Buildings of the Suq/Market," in Robert Bertram Serjeant and Ronald Lewcock, eds., San'a: An Arabian Islamic City (London, 1983), 277.

7. Scharabi, Hanna, and the editors of Le Khan al-Khalili describe the subtleties of terminology for the various types.

8. See Robert Hillenbrand, Islamic Arcbitecture: Form, Function, and Meaning (New York, 1994), 331-34, for a discussion of the terminology.

9. The exact date for Samsarat al-Nahhas is unknown, but Ronald Lewcock surmises that it is later than the Samsarat al-Majjah, which was built in the seventeenth century and is said to be linked to the endowment of the contemporary Ahmad b. al-Qasim Mosque in al-Rawdah. Lewcock, "Buildings of the Suq," 283.

10. André Raymond, Grandes Villes arabes à l'époque ottomane (Paris, 1985), 251. 11. Cees Brouwer, Al-Mukba: Profile of a Yemeni Seaport (Amsterdam, 1997), 140.

12. Volker Höhfeld noted this curious absence in Höhfeld, "Die gegenwärtige Situation Mochas als Kleinstadt," in Hans Becker, Volker Höhfeld, and Horst Kopp, eds., Kaffee aus Arabien (Wiesbaden, 1979), 26.

13. This is not to say that the merchants did not examine each other's goods and make trade inquiries there, but the structure was not meant for such purposes.

14. During the eighteenth century, European and some major Gujarati merchants had gained from the imam the privilege of bypassing the Customs House. The governor agreed that they could bring their goods on land and directly to their houses, where an official would inspect them. They would, however, be aware of activity at the Customs House, as their brokers would often report daily occurrences there to their clients.

15. Taking scholarly criticism of van Leur's peddler theory into account, Ashin Das Gupta confirms the presence of many small-scale merchants, or peddlers, who traveled the Indian Ocean trade routes. He distinguishes the peddlers from the major Gujarati merchants who dominated the trade. Das Gupta, "Indian Merchants and the Trade in the Indian Ocean, c. 1500-1750," in Tapan Raychaudhuri and Irfan Habib, eds., The Cambridge Economic History of India (Cambridge, England, 1982), 419.

16. Louis de Grandpré, Voyage dans l'Inde et au Bengale fait dans les années 1789 et 1790; . . contenant la description de Moka, et du commerce des Arabes de l'Yémen; des détails sur leur caractère et leurs mours, etc., etc. (Paris, 1801), 148.

17. The caravanserai would not be the only place in the city where pilgrims would stay. In the early nineteenth century, an anonymous American observer noted how the newly arrived pilgrims in the city had built for themselves a small provisional settlement out of reed mats along the city walls. The same source also described Malay pilgrims taking shelter in the Mosque of al-Sandal, in the southern part of the city, where he was staying. Al-Sandal, one of Mocha's smaller mosques, probably was not the only one to house such pilgrims, but other local religious structures also must have served the same purpose. Anonymous, "Caroline" Journal, 1821, Phillips 
Library, Peabody Essex Museum, Salem, Mass., Log 656 1821C. 18. 'Abdallah b. 'Ali al-Wazir, Tarikh al-yaman khilal al-qarn al-hadi 'ashar al-bijri, al sati' 'trbar al miladi, ed. Muhammad 'Abd al Rahim Jazim (Sanaa, 1985), 173, 228; and Husam al-Din Muhsin al-Hasan (Abu Talib), Tarikh alyaman fi 'asr al-istiqlal 'an al-bukm al-'uthmani al-awwal, ed. 'Abdallah Muhammad al-Hibshi (Sanaa, 1990), 84.

19. Al-Wazir, Tarikh al-yaman, 250.

20. When Sayyid Qasim Amir al-Din and Sidi 'Ali came to the city in September 1727 (both representatives of the newly declared imam Muhammad b. Ishaq), they stayed at the house of the wealthy Gujarati merchant 'Abd al-Ghafur, as arranged by the governor of the city. Thirty soldiers were placed at the door of the residence to protect the important visitors; VOC 9122, 13 Sept. 1727. That these honored guests were lodged in 'Abd al(Shafur's home confirms the practice of housing notables and important individuals in private residences rather than public structures. The historian known as Abu Talib describes the visit of the Safavid Shah Husayn's messenger and his retinue to the Zaydi imam's court in 1113/1701-2. At the end of their visit, they set up a temporary settlement of royal tents before they departed by sea from Mocha. Abu Talib, 'Asr al-istiqlal, 301.

21. The Dutch make this clear distinction in their vocabulary regarding the merchant population of the city. They refer to the tajir, or high-volume trader, as a koopman (merchant), while the small retailers from the bazaar are called mensen zan de bhasaar (people of the bazaar), houtiqueers (boutique owners), or zinkeliers (shop owners).

22. The Mocha dollar, however, was an imaginary coin, in which values were calculated but never tendered. All large-scale trade transactions would take place in values of Spanish riyals, most often converted according to the current rate from a value originally determined in Mocha dollars.

23. It is important to note that the term komasi is of Indian Ocean-region usage. The same coin would have been called harf in Sanaa. VOC: 2356,28 Jan. 1734

24. Similarly, there were neither qaysariyyabs nor any other dedicated retail structure.

25. The account says that the French captain was killed at the door of the store in Mocha ("fi bab dukkan bi'l-Mukha"). See Muhammad Zabarah, Nasbr al-arf li-nubla al-yaman ba'd al-alf, 3 vols. (Sanaa, 1985), 1:304. The Dutch specify that the French captain, Monsieur "Rickekomme," was slain in front of the French house. VOC 2447, 30 June 1737.

26. VOC 9115 .

27. Ibid.

28. Ibid.

29. VOC 9119,23 Mar. 1725.

30. See Nancy Ajung Um, "A Red Sea Society in Yemen: Architecture, Urban Form, and Cultural Dynamics in the Eighteenth-Century Port City of Al-Mukha" (Ph.D. diss., University of California, Los Angeles, 2001), 70-93, for a discussion on the identity of the merchants and other officials. 31. As an example of such exchanges, on 8 January 1706, the governor's broker went to the Dutch establishment and told them that the governor was interested in purchasing some of their goods, such as sugar, iron, and pepper. He asked Joan Ketelaar, the acting chief of the Dutch in Mocha, to bring samples of these items to the governor at his house. VOC 9115.

32. See VOC 9117, $18 \mathrm{Jan} .1723$, for a meeting at the house of 'Abd al-Ghafur. 33. Kung is called "Kongo" in the Dutch sources.

34. Newly arrived Baniyans were housed by other Baniyans, often depending on kinship or subcaste ties. The community support network was quite tight, not only within the city, but among Baniyans throughout Yemen. 35. On lodging of foreign merchants, see Jean de la Roque, Voyage de l'Arabie Heureuse par l'Océan Oriental et le Détroit de la Mer Rouge (Paris, 1741), 82. On the storage of goods, see VOC 2202, 28 May 1730. See also the incident when Baniyans were punished for storing goods directly in their homes without passing through the Customs House first; VOC 9115, 16 and 19 Apr. 1705.

36. Surveys of the houses were conducted in spring 2000 by the author. Maha al-Habshi drew all of the plans and sections, and Krista Lewis assisted on the project.

37. See Um, "Red Sea Society," 360-76, for a detailed discussion of all the houses that were surveyed. Fewer than ten historic houses stood in 2000. 38. Although the courtyard house type exists on the Arabian peninsula, other styles are more prevalent, namely the tower house, but also the reedand-mud house and the Zabid-style brick homes on the coastal Tihamah plain. Paul Bonnenfant presents these alternatives to the courtyard house in his summary of Arabian domestic architecture. He also notes that many Arabian domiciles have a great deal of ornamentation on their exteriors, unlike the traditional courtyard house, which is oriented toward the inside. Bonnenfant, "La Maison dans la péninsule Arabique," in Jean-Claude Garçin, ed., L.Habitat traditionnel dans les pays musulmans autour de la Méditerramée, vol. 3 (Cairo, 1991), 715-99, 932-39.

39. (irandpré, Voyage dans l'Inde, 171 (see n. 16).

40. The contract of the house, still in the family's possession, indicates that it was purchased in 1350/1931 by the father of the current owner.

41. The al-Mahfadi family has boarded up the passageway between room $1 \mathrm{~F}$ and the main storage area. The older sons in the family were considering turning room $1 \mathrm{~F}$ into a small room for group gatherings at which the gat leaf is chewed, a common social pastime in Yemen.

42. Bomnenfant gives several examples from Saudi Arabia and the (iulf. ()f these, see his discussion of Riyadh. Bonnenfant, "La Maison," 730.

43. Anthropologist ( iabriele vom Bruck's study of gender and spatial relations in Sanaani houses provides a strong precedent for reexamining fixed notions of gendered spaces in Yemen. See vom Bruck, "A House Turned Inside (Out: Inhabiting Space in a Yemeni (ity," Journal of Material Culture 2 (July 1997), 139-72.

44. Following official Dutch policy, some of the Dutch merchants did bring their families to Mocha to live with them, as in the case of the Colombus family, whose young son died in Mocha. VOC 9115, 28 Apr. 1706.

45. See Alexander Hamilton's account of the time he invited a merchant who had not paid his debt to the upper stories of his home and threatened to throw him from the top of the house if he did not disburse funds. Alexander Hamilton, A New Account of the East Indies (London, 1930), 35-36.

46. This did not happen often, but when it did, Europeans enthusiastically documented it. See Grandpré, Voyage dans l'Inde, 172-73.

47. The plan in Figure 7 shows only the modern door swings, but many of the now open entryways may have had doors with locks, as found in two other examples of historic houses: Bayt al-Mi'yad and the Idarah building. 48. VOC 2202, 12 July 1730.

49. VOC 2252, 11 Dec. 1731.

50. Ulrike Freitag has mentioned the case of Shibam, Hadramawt, as a city without public trade structures as well. This eastern Yemeni trade center deserves further investigation.

51. Bonnenfant, "La Maison," 775.

52. For focused studies on the Cairene rab', see Jean-Charles Depaule, Actualité de l'babitat ancien au Caire. Le Rab' Qizlar (Cairo, 1985), and Mona Zakariya, “Le Rab' de Tabbana," Annales Islamologiques 16 (1980), 275-97. 53. In the commercial zone of Cairo, of the fifty-five surveyed $r a b$ ', 80 percent were situated above a wikalah. Muhammad 'Afifi, "Les Rab'à l'époque ottomane," in Le Khan al-Khalili, 101 (see n. 5).

54. James de Vere Allen, "The Swahili House: Cultural and Ritual Concepts Underlying Its Plan and Structures," Art and Archaeology Researcb Papers (Dec. 1979), 2. 
55. While the commercial organization of the northern Red Sea port city Jiddah was contrasted with that of Mocha above, Sawakin, Mocha, and other southern Red Sea sites seem to share many similarities in organization and functional structure.

56. See Jean-Pierre Greenlaw, The Coral Buildings of Suakin (Boston, 1976). 57. Ibid., 76.

58. On the haveli house, see V. S. Pramar, Haveli: Wooden House and Mansions of Gujarat (Middletown, N.J., 1989).

59. Ibid., 86.

60. Legend attributes the coffee-drinking legacy to this famous Sufi shaykb. See Ralph Hattox, Coffee and Coffeehouses: The Origins of a Social Beverage in the Medieval Near East (Seattle, 1985), 20.

61. Al-Muhibbi, Khulasat al-atbar fi 'ayyan al-qarn al-badi' ashar (Cairo, 1284/1867-68), 500.

62. In my dissertation, I describe the historical evolution of the city and the development of these two zones. Um, "Red Sea Society," 15-57 (see n. 30). 63. Samuel Lachmann, "The Ottoman Copper Coins Struck at Mocha,"
Spink Numismatic Circular 101 (Feb. 1993), 44.

64. La Roque, Voyage de l'Arabie, 91 (see n. 35).

\section{Illustration Credits}

Figures 1-3, 6, 8-10. Photographs by the author

Figure 4. Photograph by Hermann Burchardt, 1909. Published in Eugen Mittwoch, ed., Aus dem femen. Hermann Burchardts letzte Reise durch Südarabien (Leipzig, 1926), pl. 24 bottom. Reproduced by permission of the Bibliographisches Institut and F. A. Brockhaus AG, Mannheim, Germany

Figures 5, 12. Photographs by Auguste Bartholdi, 1856. Reproduced by permission of the Musée Bartholdi, Colmar, France, reprod. C. Kempf. Museum reference numbers: Figure 5, Inv. 1P3/77; Figure 12, Inv. 1P4/90 Figure 7. Plan drawn by Maha al-Habshi

Figure 11. Photograph by Hermann Burchardt, 1909. Reproduced by permission of the Museum für Völkerkunde, Dahlem, Germany. Museum reference number K186

Figure 13. Map drawn by Eric Franzon 